\title{
I folkets tjeneste: Public service som omstridt begreb ${ }^{1}$
}

\section{AF PER MOURITSEN}

Begrebet public service er omstridt og har været det i hele sin levetid. En begrebshistorisk analyse af ordet viser, at der siden begyndelsen af 90'erne kan ses mindst fem forskellige anvendelser eller betydninger. Public service kan referere til borgernes opdragelse til demokrati, kulturel oplysning eller national integration i kulturarven. Det kan anvendes i en bred betydning, som en blanding af kvalitet og noget for alle, der sikrer at seere og lyttere bliver på kanalerne. Endelig giver TV 2 begrebet en ny, populistisk betydning af at møde befolkningen der, hvor de er. Flere af betydningerne står i et spændingsforhold til hinanden.

\section{Indledning}

Det har altid været omdiskuteret, hvad der var Danmarks Radios og senere TV 2's ansvar over for den danske befolkning. Alle husker Erhard Jakobsens Aktive lyttere og seere i 1970'erne og 80'erne. Hvilke programmer og herunder hvilken slags nyhedsformidling og journalistik har samfundet krav på? Der har aldrig været et enkelt, klassisk svar på spørgsmålet, og der er det heller ikke i dag, 18 år efter TV 2 kom til. Spørgsmålet er knyttet til det engelske begreb public service. Formålet med artiklen er at kortlægge betydningerne af dette begreb i den danske mediedebat fra begyndelsen af 9o'erne og indtil nu. Det vil sige i den periode, 
hvor et ord, der før kun anvendtes af specialister, i midten af årtiet blev et nøglebegreb.

Artiklen føjer sig til tidligere, mere overordnede fremstillinger (Søndergaard, 1995; Sepstrup, 1994; Mortensen, 1994; Medieudvalget, 1995). Søndergaards diskussion af dansk public servicefjernsyn fra 1995 sondrer nyttigt mellem begrebets anvendelse på (offentlige) medieinstitutioner, på principper for programpolitisk regulering og indholdskrav, og på mediers samfundsmæssige funktioner. Denne artikel fokuserer på indhold og funktioner. Derimod diskuterer artiklen ikke, hvordan institutionerne rent faktisk gennem programvirksomheden har opfyldt public service-forpligtelsen.

Syvertsen (1992) har beskrevet tre stadier af public service. Det første, 'offentligt gode', refererer til radio og tv som en begrænset ressource i en tid med få frekvenser, der organiseredes som offentlige monopoler. Den næste forståelse, der følger hurtigt af monopolsituationen, er idéen om tv og radio 'i samfundets eller offentlighedens tjeneste’. Der er altså tale om en pålagt forpligtelse til at udøve samfundsnyttig virksomhed for borgerne. Heri ligger dels, at man ikke må tjene (politiske) særinteresser - hvilket skaber krav om alsidighed, uafhængighed og neutralitet. Der ligger også en forestilling om, at nogle programmer er bedre end andre, og at borgerne har en interesse (uanset om de er enige heri) i at se og høre dem. Den tredje forståelse, 'i seernes tjeneste', indebærer et brud med forestillingen om en paternalistisk reformation af samfundet, idet der nu sker en orientering mod seernes præferencer. Nu betones dels programmæssig kvalitet og $v a$ riation af det, seerne efterspørger som forbrugere, dels nødvendigheden af at henvende sig bredt til hele befolkningen.

Søndergaards og Syvertsens arbejder er ikke egentlige begrebshistoriske kortlægninger. Til det formål analyseres i det følgende den måde, hvorpå ordet anvendes i talehandlinger. Det vil sige ordets forskellige mulige semantiske betydninger, de ting som ordet kan bruges til at beskrive, og dets forskellige normative ladninger (Skinner, 1989), i tekster, hvor ordet bruges til at skabe bestemte virkelighedsopfattelser, påvirke politikere eller legitimere egen virksomhed på tv- og radioområdet. Der inddrages undertiden en lidt bredere argumentationskontekst, men kun i tekster, 
hvor begrebet i øvrigt anvendes. Data er et udvalg på ca. hundrede tekster fra aviser, herunder interviews, baggrundshistorier, kronikker og ledere. Også ikke-videnskabelige tidsskriftartikler inddrages i mindre grad. Desuden folketingsdebatter ved medieforlig, lovtekster, samt institutionelle programtekster, policy-papirer og debatindlæg fra især DR og TV 2.

Det er muligt at sondre mellem fem anvendelser af public service-begrebet, på basis af hvilke Søndergaards konklusioner bør udbygges og revideres. For det første er det for tidligt at erklære det paternalistiske ideal - der analyseres med to varianter - for dødt. Især den demokratiunderstøttende betydning lever i bedste velgående. Også public service som noget kulturelt udviklende findes i moderniserede former. For det andet er der nu en markant forståelse af public service som middel til national integration, hvor kultur får en ny betydning uden den negative ladning af noget elitært og formynderisk. For det tredje ses et særligt konceptuelt skel mellem 'det brede' og 'det smalle' public servicebegreb med en voldsom spænding mellem hensynet om at henvende sig til alle og hensynet til kvalitativt gode (men også opdragende og udviklende) programmer. Endelig er det ikke længere tilfældet ,at de to kanaler opfatter denne forpligtelse på samme måde“, om end „TV 2 ikke har gjort synderlige bestræbelser på officielt at begrunde, hvordan public service-begrebet anvendes." Søndergaard (1995: 1.7). I dag er TV 2 i færd med en begrebsreformistisk offensiv, der eksplicit afgrænser en alternativ populistisk forståelse af public service fra DR's forståelse.

\section{Public service-begrebets struktur og kontekst}

Public service-begrebet har en række faste dimensioner: For det første en bestemmelse af den offentlige interesse eller almenheden, jf. begrebets første led. Skal tv og radio levere det, som folk har en interesse i at se, fordi det er udviklende og vigtigt - og hvad er i givet fald udviklende og vigtigt? Skal folk have det, de efterspørger som forbrugere? Eller det, de ellers ikke ville have muligheden for at se og høre på det kommercielle mediemarked? Er offentligheden et demokratisk eller nationalt folk eller en samling af individer med forskellig smag og behov? For det andet en be- 
stemmelse af relationen mellem producent og publikum ('service'), herunder de to parters roller, forpligtelser eller gensidige forventninger om deltagelse eller passivitet, imødekommenhed, opdragelse mv.

Ændringen i begrebets strukturelle kontekst fra monopolstatus i en mediemæssigt lukket nationalstat til markedsbetingelser og globalisering har påvirket public service-forpligtelsens kontroversialitet. Tidligere rejste forpligtelsen forventninger om (manglende) politisk neutralitet og manglende sans for 'almindelige menneskers' præferencer. DR kunne kritiseres for at være for venstreorienteret, kulturelt elitær eller kedelig, fordi dets monopolstatus ikke blev udfordret. Under markedsvilkår er problemstillingen, hvordan public service-medier kan udfordre, være alternativ til eller supplere kommercielle kanaler - herunder om det overhovedet er muligt og realistisk at være seriøs, smal eller elitær. Hvor problemet tidligere var, at et sendemonopol kunne misbruges i forhold til befolkningen og bevilgende politikere, har samme befolkning og politikere nu forventninger om, at 'monopolet' (på licensfinansiering) måske ikke bruges godt nok i forhold til markedet, selv om der ikke er enighed om, hvad der er godt nok.

En dominerende fortolkning af public service har altid impliceret programmer, som befolkningen ellers ikke ville se eller høre. Tidligere, fordi befolkningen ikke havde forudsætninger (uddannelse og kvalitetssans) til at efterspørge den. $\mathrm{Nu}$, fordi befolkningen ellers ikke ville kunne se eller høre den, selvom de havde lyst. Dermed er der også sket et skift i begrebets normative ladning. Det, som man før blev påtvunget, fremstår nu som skrøbeligt, med færre negative konnotationer af folket mod eliten, og flere positive konnotationer af nationen, individerne og fællesskabet mod markedet og globaliseringen. Uanset indholdet fremstår public service som truet, fordi den er dyr, dansksproget og udtryk for en prekær, professionel balance i den hårde konkurrence - hvor den tidligere associeredes med monopolets selvgodhed og inerti.

Begrebet anvendes næsten altid (selv)evaluerende og normativt, ofte i forfalds- eller udviklingshistorier, hvor der tilskrives ære eller dadel for at have levet op til idealet eller ej. Søndergaard 
noterede i 1995 „en mere eller mindre åben kamp ikke blot om, hvad der skal forstås ved begrebet, men også om hvilke institutioner der med størst ret kan kalde sig for 'public service.'“ (Søndergaard, 1995: 1.1). Siden er kampen om det omstridte begreb (Connolly, 1993) intensiveret, og dets brugere er sig denne strategiske strid bevidst. Mens man i DR erkender „til enhver tid [at] være deltager i en åben diskussion af hvad public service skal være“ (Aaberg, 1999: 5), påpeger TV 2, at „public service-begrebet er ... ikke entydigt og ikke statisk,“ ja, det får „forskellig betydning for forskellige virksomheder." (TV 2, 1995: 50-51).

\section{I: Public service som demokratiunderstøttende og -uddannende}

I materialet ses umiddelbart en sondring med rødder i public service-institutionens tidlige historie, mellem henholdsvis et demokratiunderstøttende og et kulturelt (ud)dannende element. De to forpligtelser associeres med en række klassiske programtyper, den første især med nyheder, aktualitetsudsendelser/baggrund og debat, den anden med kultur(debat), kunst og bredere oplysning. DR's bestyrelsesformand taler om „et kulturpolitisk og samfundsforpligtende, kollektivt finansieret tilbud, som stilles til rådighed for alle. En slags demokratisk og kulturpolitisk grundforsyning af nyheder, baggrund, kultur, kunst, videnskab og debat" (Aaberg, 1999: 4). Der er dog en vis udvikling i de to public service-begreber, der undertiden optræder sammen som to aspekter af den samme forpligtelse til at vedligeholde en politisk og kulturel offentlighed.

Det første public service-begreb forbindes med ideen om et folk af borgere, der skal sikres ,handleevne i et demokratisk samfund“ (Aaberg, 1999: 3), og med en række relaterede funktioner, der ikke mindst for danske politikere tilsyneladende er vigtige. For det første med formidling af faktuel viden og nyheder, herunder baggrund og analyse, især af samfundsforhold (økonomi, politik, internationale forhold, partiernes synspunkter), der er forudsætningen for begrundet stillingtagen. For det andet med en idé om pressen som borgernes forlængede arm i kontrollen med politikerne. For det tredje med pressen som kommunika- 
tionskanal mellem borgere og politikere. For det fjerde med medierne som et demokratisk forum for debat. Og endelig for det femte med en uddannelsesmæssig, mobiliserende funktion. Tv og radio skal myndiggøre og motivere borgeren.

Idealet formuleres fra politikerside prægnant af Marianne Jelved: Den nationale presse, især tv, skal „udover at være kritisk“ - som en „vågen terrier overfor magthaverne“ - skabe „det offentlige rum, hvor den offentlige samtale kan finde sted“. Her skal politikerne kunne „formidle deres viden og ... forklare og begrunde deres beslutninger, kompromisser og stillingtagen," men pressen skal også ,brug[e] ventetiden i en forhandlingsfase til at belyse problemerne, deres baggrund, deres forskellige løsningsmuligheder ... og konsekvenser (...) Så havde læserne, lytterne og seerne en bedre mulighed for ... at blande sig i debatten “ (Jelved 1992: 15). Socialdemokraten Carsten Hansen efterspørger et „åbent, alsidigt og upartisk offentligt kommunikationssystem,“ der er vigtigt, „, når man skal udvikle sig som samfundsborger“, og som kan hindre „en endnu stærkere opsplitning mellem informationsstærke og informationssvage grupper“, hvor nogle „bliver kastet af den karrusel, der hedder oplysning, information og debat, og som sætter én i stand til at tage kritisk stilling og være deltagende borger i et demokratisk samfund“ (Hansen, 2000: 2627).

Forståelsen er tydelig i lovgrundlaget (Bekendtgørelse af Lov om radio- og fjernsynsvirksomhed, § 10) og markant i Medieudvalgets betænkning fra 1996, der taler om „fremdragelse af diskutable forhold i samfundets politisk og administrative strukturer, såvel som i organisations- og erhvervslivet“ (Medieudvalget, 1995: 2.2.3). Den forbindes især med klassiske nyheder, aktualitetsstof og debat og med idealerne om politisk upartiskhed eller neutralitet, uafhængighed af partipolitik, og journalistisk saglighed og troværdighed. Betydningen mobiliseres i forbindelse med internetbaserede tjenester som DR Online, der bør kunne „udvikle sig til fremtidens elektroniske forsamlingshus.“ (DR, 1999: 10). Modsætningen er radio og tv, der kun sender underholdning, eller hvor nyhedsformidlingen er overfladisk eller andenhånds. En sådan karakteristik af nyhedsformidlingen kommer til udtryk, når det påpeges, at nyhedsudsendelser på kommercielle kanaler 
- og for en række kommentatorer på TV 2 - er dårligere end på DR (fx Knudsen, 1999: 29). Det ses tilsvarende når kvaliteten af især politisk journalistik kritiseres i diskussioner af mediernes magt og journalisters overfladiske research, medansvar for spin, enkeltsagsfokusering eller manglende upartiskhed.

Idealet ses også med tilsvarende formuleringer i det „idégrundlag“, der blev vedtaget af DR's bestyrelse i 1994. Her associeres det eksplicit til nødvendigheden af uafhængighed „af økonomiske og politiske særinteresser“. Betoningen af det demokratiske indebærer her lidt mere fokus på egentlig, effektiv deltagelse (i forhold til tidligere opdragelse til demokrati) og „reel indflydelse“ på selve programvirksomheden. Det fremhæves, at dette kun kan opnås, hvis alle danskere kan modtage programmerne og ønsker at se dem - herunder, at man af den grund må være imødekommende i forhold til lytteres og seeres ønsker (DR, 1995: 7). Her ses en bevægelse væk fra en lidt gammeldags, paternalistisk bestemmelse af opdragelse til demokrati. Men der er i materialet en meget større villighed til at associere public service med en (ud)dannende, bevidstgørende funktion i forbindelse med det demokratiske begreb, der sjældent forbindes med noget elitært, end, som vi skal se, i forbindelse med den kulturpolitiske forpligtelse. Således tør Christian S. Nissen, der ellers ofte langer ud efter 'kultureliten', i forbindelse med målsætningen ,at gøre borgerne i stand til at handle i et demokratisk samfund" tale om, at DR skal vedkende sig noget „normdannende, noget holdningsdannende, noget opdragende“, ja, „DR skal blive ved ... og sige: Vi ved godt, hvad vi tror seerne har behov for, selvom de ikke selv er klar over det." I samme dobbeltinterview bruger Anne Knudsen begrebet - også i forbindelse med den demokratiske funktion - „et neo-modernistisk oplysningsprojekt“ (Knudsen m.fl., 2005).

\section{II: Det kulturelt udviklende og opdragende public service-begreb}

Idealet om en 'kulturpolitiske grundforsyning' er i dag mindre fremtrædende. I Medieudvalgets betænkning fra 1995 hedder det, at programlægningen tidligere var „stærkt præget af et ønske om at opdrage befolkningen kulturelt. I Radioens barndom (...) 
gjaldt der et klassisk dannelsesideal som målestok for programindholdet. Frem for alt den klassiske musik skulle medvirke til at højne befolkningens kulturelle stade. I 196o'erne blev radio og tv til en del af bestræbelserne for at demokratisere kulturen, bl.a. gennem en aktiv statslig kulturpolitik. Kunsten i alle dens former fra den mest eksperimenterende til den klassiske blev anset som et demokratisk gode, som via medierne skulle formidles til hele befolkningen." (Medieudvalget, 1995: 2.2.3). Public service handler her om opdragelse inden for et givet kvalitetsunivers, også i den kulturradikale variant, hvor kultur og kunst kan gøres tilgængelig for alle. Kultur er svært, eventuelt eksperimenterende og provokerende, noget, der skal forklares. I undersøgelsens nyere materiale er forståelsen ikke dominerende, og dens komponenter og perspektiv uekspliciterede, udover at sikre en „mangesidig kulturel udvikling“ (Nissen, 1994: 3), skræmmebilleder om (fin)kulturelle elementers (radiosymfoniorkestret) forsvinden fra DR, og lovteksters angivelse af områder som gøres til særlig genstand for public service-dækning. Forståelsen ses ofte mest gennem sin modsætning, det populære, lavkulturelle, forbundet med markedsgørelsen, som når Jytte Hilden kunne brokke sig over, at „det, der var tænkt som en konkurrence på kvalitet, er ved at udvikle sig til en konkurrence på underholdning, quiz-programmer og billige serier“ (Thygesen, 1993: 1). Kun få stikker hovedet ud som Thomas Bredsdorff (1995: 8), for hvem „der findes godt tv i alle genrer, det bliver det bare ikke public service af“, idet „public service (...) er det der udføres for det almene vel, uanset om den er efterspurgt af mange eller ej.“ Ellers tør få tale om opdragelse og elite uden at ironisere over „lugten af sur tavlesvamp, skolebænk [og] tugt“ (Libak, 1996: 7). Jørgen Ramskov fra DR mener således at: „DR1 er ikke kulturopdrager ... vi skal ikke sige: Det her skal I se, for ellers er det skidt for jer selv eller samfundet. Dét er røget ud af tandpastatuben, og vi får det ikke ind igen“ (Carstensen, 1998: 6). Mens mange kritiserer DR for at være kommerciel, for at burde holde sig for god til børne-MGP, og for at have opgivet kvalitetsprogrammer af den ene eller anden slags, vil næppe mange se sig selv i Christian S. Nissens idé om en „højpandet niche for økonomisk bedrestillede og kulturelt bevidste“ (Libak, 1996: 7). 
Men det kulturopdragende public service-begreb er ikke helt dødt. Morten Albæk mener, at „når DR forfalder til at tjene folket, så bliver det til en leflen for den laveste fællesnævner. DR har som institution en forpligtelse til at lægge overliggeren højere eller i hvert fald anderledes end de andre (...) til at udfordre, provokere, anstøde og bevæge os, og det behøver ikke at være dybt elitært. Se bare 'Drengene fra Angora'“ (Baadsgaard, 2005: 6). For Poul Nesgaard skal public service-stationerne, „skabe programmer, der udvikler os og ikke kun bekræfter os i vores egen fordomsfuldhed og snæversynethed“ (Rørbech, 1998: 16). I DR er dette public service-element anbragt på ydertidspunkter og særlige kanaler. P1 skulle for Slumstrup i 1992 være kanalen for „det kommende“, „virkeligheden bag de vedtagne sandheder ... kanalen for det kunstneriske eksperiment“ (Slumstrup, 1992: 4). Men selv det provokerende må i dag helst ikke smage af opdragelse. I et interview hedder det fra Mette Davidsen-Nielsen og Gitte Rabøl, ledere af DR2, at de på denne kanal „måtte forholde sig til, forvalte og forny en lang række konventioner og fordomme om kulturradikalt smagsdommeri, kulturarv og public service. (...) Engang var public service lig med opdragelse, men det er det ikke længere (...). Dengang der virkelig var ballade i DR, var da de kulturradikale gjorde oprør mod den gamle, patroniserende tilgang. Men med tiden sker der jo det, at den nye, fornyende position selv bliver til det etablerede. (...) Den fornyelse, vi er i gang med, handler nok om et skift til at rumme forskellige positioner." (Kaarsholm, 2006: 14-15).

I stedet for det gamle kulturopdragende begreb ses en række konceptuelle skift, der også rummer en ny betydning (jf. også nr. 4 nedenfor) om markedskompensation i et globaliseret og kommercialiseret medieudbud. For det første kan det betyde valgfrihed også til programmer, der kun interesserer de få. Kultur er her ikke et oplysningsprojekt, men en (smal) præference blandt andre. Der skal også være noget for dem, der vil have kulturdebat og svære film. Man skal ikke kun se på seertal eller screene musikudvalget med popularitetstests. Der skal, som der står i radio- og fjernsynslovens §10, sikres „alsidighed“ og „mangfoldighed“, og programvirksomheden skal ,afspejle bredden i produktionen af kunst og kultur“. Hensynet til alsidighed gør det her muligt at 
bruge public service- begrebet om programmer, der ikke traditionelt har været associeret hermed, for eksempel 'snævre' sportsgrene (Brandt, 1998: 5). For det andet indebærer det en stadig betoning af indholdsmæssig kvalitet, uanset genre, igen kontrasteret til det billige udenlandske. Public service er her også produktion af 'ordentlig' underholdning. ('Taxa', 'Langt fra Las Vegas'). For det tredje associeres det med at understøtte dansk kultur og dets talenter, idet dansk produceret automatisk sidestilles med kvalitet. Denne betydning knyttes fra midt i 9o'erne til først bekymringen om at miste „den nationale særegenhed“ og derved blive „et fattigt land“ (Balsby, 1994: 5), og derefter til et egentligt ny-nationalistisk integrationsprojekt, som nu behandles.

\section{III: Det nationalt-kulturelt integrerende public service-begreb}

I forlængelse af medieglobaliseringen og svarende til et generelt skift i dansk politisk kultur (Hedetoft, 1999; Mouritsen, 2006) har den kulturpolitiske forpligtelse i begrebet undergået en markant forandring. Firkantet sagt ses en glidning fra kultur som dannelse og personlig udvikling inden for et givet kvalitetsunivers til kultur som noget nationalt (og regionalt og lokalt) partikulært, som vedligeholdes som identitet og integration af fællesskabet. Med glidningen, der hænger sammen med de mange billige udenlandske programmer og folkelig efterspørgsel af dansk underholdning og nyhedsformidling (Søndergaard, 2003), har det kulturpolitiske public service-aspekt samtidig mistet sin elitære konnotation. Den særlige nationale kultur er ikke finkultur, og slet ikke noget der udfordrer og provokerer, men noget skrøbeligt man bør „værne om og formidle“ (Baadsgaard, 2005: 7). Ja for så vidt public service skal være „samlende kit i et ellers opsplittet samfund, er det vigtigt, at mange bryder sig om det, vi laver." (Erichsen, 1999: 23). Den latente konflikt er ikke befolkningen mod kultureliten, men nationen mod globaliseringen.

Kultur bliver her for det første til fællesskab og som sådan, vigtigt for den enkelte (tilhørsforhold) og for samfundet (sammenhængskraft). Begge dele aktualiseres også af den mediemæssige fragmentering i forskellige platforme (som DR derfor også skal 
befinde sig på), forskellige medieforbrugsmønstre/tidspunkter (som DR skal indrette sig efter), og forskellige seergrupper (som alle skal opleve DR henvende sig også til dem) (DR, 2005). Det er "alle danske lyttere og seeres behov for foelles oplevelser“ (Aaberg, 1999: 6). Udfordringen er at „bidrage til kultur, identitet og sammenhængskraft i Danmark, så vi kan være et modsvar til det internationale udbud.“ „Public service skal fortsat være en del af danskernes hverdag og bevidsthed, der er med til at holde samfundet sammen,“ ja DR skal „som en central kulturinstitution [skabe] øget sammenhæng i samfundet i stedet for splittelse og fragmentering“ (DR, 2005: 6-11). Udbuddet af tv-kanaler „,er en del af forklaringen på, at vi ikke længere er en homogen gruppe ... med et minimum af fælles, kollektive værdier at samles om", mener en socialdemokratisk politiker (Hansen, 2000: 26-27). For DR's Jesper Vognsgaard skal ,den store historie, verdenshistorien ... hænge sammen med den lokale, den nære historie“ (Baadsgaard, 2005: 7). Og for Lisbeth Knudsen påvirker samme hensyn sågar opfattelsen af nyheds- og aktualitetsudsendelser, der ikke blot skal „forsyne befolkningen med oplysninger. De er også med til at give os et fællesskab, en national ramme om vores liv. Gennem nyhederne får vi en forsikring om, at der findes en slags sammenhæng“ (Knudsen, 2002: 88-89).

For det andet bliver kultur til partikulær kollektiv identitet, dvs. vores kulturarv: særlige værdier, traditioner og frembringelser, typisk associeret med dansk sprog. Det er „alt det der gør forskellen mellem en tilfældig gruppe mennesker og et samfund med et projekt“ (Aaberg, 1999: 4). DR skal „værne og formidle om det scerligt danske" (Baadsgaard, 2005: 6). I DR for dig og hele DanmarkDRs mediepolitiske udspil for 2007-10 - er det nationale perspektiv stærkt fremhævet, mens det demokratiske aspekt først nævnes langt henne i teksten: „Det danske er og forbliver et centralt udgangspunkt for DR. Vi informerer, underholder og udfordrer med afsæt i dansk sprog, kultur og natur. Vi belyser danskernes rolle i en stadig mere globaliseret verden (...) Vi vil sætte endnu mere fokus på de danske historier og de danske udfordringer ... [og] give danskerne kendskab til hvordan livet leves og forstås i Danmarks mangfoldige sociale, geografiske og kulturelle virkelighed." I forhold til børne- og ungdomsprogrammer er det na- 
tionale 'vi' helt eksplicit: „Børn og unge er en særligt prioriteret målgruppe, som vi vil formidle viden til - om vores land, vores sprog, vores historie og vores værdier“ (DR, 2005: 13).

Public service som national integration er bredt accepteret. I den gældende Public Service-kontrakt for 2003-06 hedder det, at „DR skal lægge særlig vægt på sin rolle som initiativtager til og formidler af dansk sprog og kultur, herunder den danske kulturarv" (Kulturministeriet, 2002: 1). Mens denne rolle var stort set fraværende også i DR indtil midt i 9o'erne, anfører Christian S. Nissen i 1999 vigtigheden af ,programmer der har deres udgangspunkt i danske værdier, oplevelser, sprog og kultur ... baseret på dansk identitet (...) fordi vi ved, at så længe vi ønsker at beholde et samfund præget af danske værdier, er det vigtigt at der er nogen, der fortæller den danske historie“ (Nissen, 1999: 22). Paradenumre er programmer om danskernes kollektive historie som Matador og senest Krøniken, der ofte nævnes i teksterne, og som Kenneth Plummer fremdrager tidligt og sent.

I det lys er det dog paradoksalt, at DR samtidig accepter en høj grad af pluralisme og fragmentation. DR's løfte i det seneste mediepolitiske udspil om „noget at samles om“ står lige efter et endnu mere vigtigt løfte (løfte nr. 1) om „frihed til selv at vælge hvad og hvornår“. Hårdt trukket op bliver konsekvensen, at det der er at samles om simpelthen er kanalen som sådan - ikke et fælles set eller hørt indhold. (DR, 2005: 4).

Dette vilkår anvendes ikke til at problematisere ideen om en enhedskultur. Man søger ikke at dekonstruere det nationale som fælles identitet, men derimod at dekonstruere ideen om én givet (høj)kultur. Opgaven er ikke ,at opdrage til en enhedskultur ... “ og „public service, og dermed DR, må afspejle og forholde sig til nutidige livsvilkår, hvor forskelligheden også er vigtig. Derfor skal public service give plads til at udforske og afprøve både det fælles og forskellighederne i det danske samfund“ (DR, 1998: 9-10). Interessant nok er der ikke for alvor, i forbindelse med det pluralisme-accepterende, en betoning af 'multikulturel' (etnisk eller religiøs) pluralisme. Pluralismen er snarere livsstilspluralisme, markedssegmentering (fx Jensen, 1996: 3), eller regionale forskelle (selvfølgelig betonet af TV 2) (TV 2, 1995: 9). Der er undtagelser. Finn Slumstrup gør sig til talsmand for P1 som en niche for 
mindretal, det „afvigende“. Det er en meget sigende betegnelse der, paradoksalt nok for en P1-chef, der har været leder af Dansk Flygtningehjælp, modstilles „det almene“, som program 1 også skal have med (Slumstrup, 1992: 4). DR2 har på det allerseneste lavet DR2 $i$ farver, hvor „vi gerne vil behandle det mangfoldige Danmark gennem emner som etnicitet, tro, seksualitet og normalitet“, ud fra betragtningen, at „engang var public service ensbetydende med opdragelse, men det er det ikke længere ... Så vi spurgte os selv: 'Hvis vi ikke længere opdrager folk til en enhedskultur, hvad gør vi så?’ Så skaber vi et rum, hvor folk er forskellige“ (Kaarsholm, 2006: 14). Intet af det er dog udtryk for 'public space sharing', hvor minoritetsoffentligheder kan vedligeholde deres 'sammenhængskraft', værdier og identitet. I Public service-kontrakten mellem DR og kulturministeren (2003-06) står der, at „DR skal i sin samlede udsendelsesvirksomhed medvirke til at fremme integration“. Men når der heri, og i tilladelsen til TV 2 til at udøve public service-programvirksomhed, tales om, at programudbuddet skal vise „mangfoldighed af kultur, livsopfattelse og levevilkår“, er det „i de forskellige dele af landet“ (Kulturministeriet, 2002: 1; 2003: 7). Det almene er det danske og den regionale mangfoldighed, og det etnisk-religiøst afvigende er et eksotisk spice of life.

Undertiden kan den kulturbærende og nationalt integrerende forpligtelse dog italesættes med en lidt anden karakter, nemlig som vedligeholdelse af et fælles kommunikationsrum, der spejler, hvad der rører sig blandt danskere i Danmark - „den rejse vi sammen skal gøre ind i det 21. århundrede“ (Baadsgaard, 2005: 7). Ikke nationen, men samfundet og den fælles dagligdag bliver her det afgørende. „Tv er både en uadskillelig del af samfundet, samtidig med at det reflekterer det samfund, seeren er en del af (...) Tv er en del af samfundet og hverdagen, men skaber samtidig et rum, hvor samfundet og ens egen situation diskuteres, portrætteres, grines af osv.“ (DR, 1998: 9) Vi er her langt både fra det højkulturelle og fra den nationale kultur (sproget, kulturarven). Fraset den højstemte betoning af det refleksive og pluralistiske, behøver ideen om et fælles kommunikationsrum ikke være så langt fra den nypopulistiske opfattelse, der behandles om et øjeblik. 


\section{IV: Det 'brede' og det 'smalle' public service-begreb}

Den fjerde forståelse af public service er udbredt i DR, i Socialdemokratiet og blandt medieforskere, men udfordret af den borgerlige regering og af enkeltpersoner, der tilslutter sig en elitær variant af begreb 1 og 2. 'Bred' public service er ikke som de tre forrige begreber karakteriseret ved et bestemt indhold, men kombineres ofte med én af dem. Ideen med det er, at befolkningen skal sikres adgang til kvalitetsudsendelser, og at disse må have en grad af tilgængelighed eller bredde (eller skal kombineres med udsendelser der har en sådan bredde), der sikrer at størstedelen af befolkningen faktisk ser eller hører dem og dermed får noget for licensen. Det er en del af begrebets anvendelse at man vedgår sig en spænding eller udfordring. Begrebets modsætning er ikke det elitære. Modsætningen er enten det der kun er elitært ('smal' public service, der ikke længere vil være 'public' i betydningen set af de fleste), eller modsat det der, i ønsket om at være populært, afskaller så meget kvalitet, at det ikke længere er 'public' i betydningen et alternativ til det kommercielle marked.

Mens 'smal' public service er det, der ikke ville blive produceret på et marked, fordi det ikke er lønsomt (og, underforstået, har kvalitet - ofte som danske programmer), er det brede begreb så at sige den grad af kvalitet eller den andel af kvalitetsprogrammer som en public service-kanal kan opretholde under frie markedsvilkår, hvis man stadigvæk skal henvende sig til alle danskere. Her ses en ironisk forskydning. Mens borgerlige kritikere i monopoltiden ofte kritiserede DR's udbud for at være for smalt, hedder det nu ofte, at kanalen spilder licenskroner og udøver unfair konkurrence på det kommercielle marked, når programudbudet ikke kun omfatter det smalle og dyre, men også det brede. Her underforstås det, at DR kun skal sikre reel valgmulighed ved så at sige at kompensere forbrugeren for markedsfejl. Public service bliver at sikre muligheden for kvalitets-tv og -radio. I de allerseneste år er der en tendens til at se public service, med Christian S. Nissens ord, som „synonym med selve den kvalitative ydelse“. Man kan nu tale om et marked for public service-ydelser (bestemte programmer, der kræver offentlig subvention), som DR ikke bør have 'monopol' på, og om hvilke staten kan kontrahere med kommer- 
cielle operatører (Kulturministeriet, 2006: 6; Nissen, 2006; Berlingske Tidende, 2006). Her kommer den borgerlige regering i konflikt med ideen om en national forpligtelse - til demokratiet, det finkulturelle eller den nationale kulturarv - fordi alle disse formål indebærer, at flest mulige rent faktisk udsættes for påvirkningen. At påpege det skisma er blevet en dominerende strategi. I 2002 mente formanden for DR's bestyrelse (Aaberg, 2002: 7), at „det ville - kulturpolitisk og demokratisk set - være en fatal misforståelse at indsnævre definitionen og gøre public service til 'en nichevirksomhed for de i forvejen velforsynede'“.

I et indlæg med den nu karakteristik inkluderende titel „DR for alle danskere“ noteres det, at DR „som en samfundsforpligtet institution, der arbejder 'i folkets tjeneste' selvfølgelig også [må] tage hensyn til licensbetalernes ønsker. Det er for DR afgørende at alle danskere i løbet af en dag eller en uge kan finde et passende antal DR-programmer, de gerne vil se eller lytte til (...) Derfor skal der i DR være programmer for alle danskere. Det er en vigtig del af den samfundskontrakt, vi har med alle danskere“. Det er nu blevet et selvstændigt hensyn at holde alle seere på DR - altså ikke kun af hensyn til de udviklende forpligtelser. Hvis publikum svigtede, „ville vi både svigte licensbetalerne og vores kulturpolitiske og demokratiske forpligtelser“ (Nissen, 1999: 20, mine fremhævninger). Public service bliver her de præferencer, der udtrykkes på mediemarkedet - ikke den ideale offentligheds indhold af det befolkningen har gavn af at se og høre. Nissen tager i en vis forstand et skridt i retning af det populistiske public service-begreb, der beskrives nedenfor. Man kan også sige at han forholder sig realistisk til politisk legitimering af public service. Mens en elitær forståelse kunne opretholdes i en monopolsituation - hvor der ikke var noget alternativ, og hvor det var en del af et bredere formynderisk-socialstatsligt projekt - så ville den, og især dens offentlige licensfinansiering, nu være fuldstændigt urealistisk (Nissen, 2005). En central del af legitimeringen, der gør en dyd ud af nødvendigheden, er at ophoeve modsætningen mellem det smalle og det brede - kunststykket at „gøre det gode populært og gøre det populære godt“ (Aaberg, 2002: 6). 


\section{V: Det ny-populistiske public service-begreb i TV 2}

Vi har set en voksende erkendelse af nødvendigheden af både at levere kvalitet og henvende sig bredt. I TV 2's selvfremstilling ses i dag et helt nyt begreb om public service. I en central tekst af TV 2s programchef (Damgaard, 2006), der citeres tæt og med fremhævninger i det følgende, er der ikke længere nogen konflikt mellem kvalitet og på den anden side de præferencer, der udtrykkes på mediemarkedet. „TV 2 er både en børs og en katedral“. , Sådan er TV 2s public service vilkår indrettet - at vi på væsentlige stofområder - nyhedsformidling, oplysning, kunst og underholdning - lader det kreative og det kommercielle gå hånd i hånd. Vi skal ramme markedet med mening." Overvindelsen (benægtelsen) af en konflikt mellem kvalitet og det brede/kommercielle sker gennem retoriske greb, der sætter lighedstegn mellem public service og befolkningens synsvinkel, mens afspejling af denne befolkning investeres med positive konnotationer og patos.

Først konstrueres en modsætning mellem public service som seernes interesser og på den anden side sarinteresser, der identificeres med producenter, der vil bestemme, hvad der er godt. Derved fremstår programmer, der påberåber sig public service ud fra et kvalitetssynspunkt (fx nr. 1 og 2), som det modsatte: „På TV 2 er det vores opgave at sætte seernes og virksomhedens interesser først med udgangspunkt $i$ public service-kravene - ... [modsat] når scerinteresser ønsker, at vi skal give køb på den redaktionelle dispositionsret".

Dernæst investeres seernes præferencer med værdighed og integritet gennem anvendelsen af positive/negative markører: „... Utzon har engang sagt, at byggeri skal tjene folks velbefindende. (...) det blev sagt i en tid, hvor de herskende arkitekturstrømninger mente at med det rette byggeri kunne man lave mennesket om. Utzon var på samme tid mere beskeden og mere ambitiøs: At sørge for folks velbefindende! Med tv er det ikke anderledes: Med respekt for seernes intelligens, dømmekraft og lyst til at blive underholdt at tilbyde en relevant, væsentlig og mangfoldig programflade, der har seernes velbefindende for øje." Det er dårligt at lave folk om. Og der er ingen modsætning mellem underholdning og ,intelligens“ og „dømmekraft.“ 
Der er heller ingen modsætning mellem „en relevant, væsentlig og mangfoldig programflade“ og „seernes velbefindende“ eller „lyst til at blive underholdt." Det skyldes, for det tredje, at relevanskriterier nyfortolkes: „Underholdnings- og dokumentarprogrammer på TV 2 tager seerne med storm. Deres liv, deres verden, vores samfund. Relevans får et nyt indhold." Væsentlighed og relevans forbindes med "historier set fra seernes eget synspunkt.“ TV 2 vil således „, være modtagerorienteret. Det ligger noermest selvfølgeligt i selve begrebet 'public service'. Derfor taler vi dagligt om nærhed på TV 2. Om seernes dagsorden. Om identifikation“. Dette er til forskel fra (det gamle) DR, der „var afsenderorienteret. Der måtte kun underholdes i weekenden. Disneytimen var en gave til folket - en gang om året, 1. juledag. “

For det fjerde bliver også dette at møde og afspejle befolkningen til noget sofistikeret og nærmest avant garde-agtigt. TV 2 skal på Hegeliansk vis tyde og tolke folkesjælen, før den konkretiseres: Man skal „forny, overraske og reflektere de drømme og lyster, som analysebureauerne endnu ikke har fanget,“ være „seismograf“ og „give et bud på, hvor seernes dagsorden er på vej hen. " Det folkelige bliver dynamisk og smart, tidsånd på en positiv måde.

For det femte associeres markedets betingelser med innovation, professionalisme, opfindsomhed og allestedsnærværenhed - modsat det stive og „statsautoriserede“.TV 2 er et billede på den nye verdensorden efter 1989 (og DR symboliserer l'ancien regime): „TV 2 nyhederne bryder igennem med Murens fald i Berlin i 1989. Først til stede. Mest troværdig. En ny verdensorden bliver skabt i de dage. En verdensorden, TV 2 selv føler sig som en del af“. TV 2 er „størst og mest moderne, “ „i dynamisk forandring styret af gode ideer."

For det sjette associeres der til en populistisk, anti-kulturradikal folkelighed. Man knytter et bånd til ,den altovervejende del af den danske befolkning“ ved at udfylde „et stort hul på den folkelige midtbane“ („DR førte ... bolden frem i venstre side“). Man er affirmativ, ikke negativ: „Vi supplerer gerne samtidsbilledet af Danmark og danskerne, hvor der fokuseres på muligheder og ikke på begrænsninger (...). Vi gør en dyd ud af at turde være FOR og ikke pr. automatik IMOD.“ 
Endelig italesættes en overensstemmelse mellem seerpræferencer og en stadigt konstitueret Rousseausk folkevilje. Det er et samtidsorienteret fællesskab om hverdagsproblemstillinger, som kanalen både reflekterer og skaber, og som trækker på markører („værdier“, „dansk kultur og identitet $i$ TV 2s fortolkning“), der ligner det nationalt integrerende public service-begreb. Men modsætningen, der antages, er dog snarere folket og samfundet versus smagsdommerne, end nationen versus globaliseringen. „Seernes dagsorden er altid i bevægelse. Men i et konsensussamfund som det danske forandrer vi os i stort omfang sammen! (...). Vi skildrer fællesskaber - og vi skaber fællesskaber med vore programmer (...). Interessen for samfundets fælles værdier - vore børns skole, vores DSB, vores udfordring med integrationen, vores boliger - er større en nogensinde. Fra jeg til dig og mig. Fra os til vores ... Det er TV 2s opgave ... at reflektere denne dagsorden. At skildre og skabe fællesskaber omkring moderkanalen [sic] TV 2 (...). At reflektere samtiden og sætte den i perspektiv. At respektere seernes adfærd og ønsker om at opleve det samme samtidigt“

\section{Konklusion}

Debatten om public service viser en slående uenighed om, hvad begrebet overhovedet betyder. Alle er enige om, at Danmark skal have bedre public service. Men de analyserede betydninger står i et spændingsforhold, der både afspejler strategiske modsætninger mellem aktører og institutioner og den parallelle eksistens af flere forskellige hensyn, som næppe alle kan forfølges samtidigt. Man kan ikke både tilstræbe indholdsmæssig kvalitet i smalle kulturprogrammer og samtidig søge at udvikle og danne befolkningen kulturelt og demokratisk og give befolkningen, det den rent faktisk efterspørger. Man kan ikke både gøre høje seertal til et nødvendigt element i public service og samtidig insistere på, at DR især skal koncentrere sig om at kompensere befolkningen for det, markedet ikke leverer. Og man kan ikke både efterspørge udfordrende, eksperimenterende og provokerende udsendelser og insistere på en særlig nationalt integrerende opgave, der skal samle danskerne om deres fælles værdier og kulturarv. 


\section{NOTER}

1. Artiklen rapporterer foreløbige resultater af delprojektet om public service-begrebet inden for forskningsprojektet Dansk public service på journalistikkens betingelser: Udviklinger, dilemmaer, visioner, der i 2006-2008 støttes af Radio- og TV-rådet. Tak til Carolina Kamil og Martin Carstensen for energisk dataindsamling og til projektgruppen for kommentarer.

\section{REFEREN CER}

Aaberg, Finn (1999). „Public Service i Danmark ved en korsvej“, pp. 3-5 i Danskernes DR. - DRs ønsker og forslag til ny mediepolitisk aftale, København: DR.

Aaberg, Finn (2002). „DR's forventninger til det kommende medieforlig“, pp. 6-8 i Public Service Rådet, Medieforlig 2002 og public service, København: Public Service Rådet.

Baadsgaard, Trine (2005). „DR skal have noget på hjerte“, pp. 6-7 i DR for alle - Et magasin om public service, København: DR.

Balsby, Egon (1994). „Nissen på en knivsæg“, Weekendavisen, 5. august 1994, 1. sektion, p. 5 .

Bekendtgørelse af Lov om radio- og fjernsynsvirksomhed.

Berlingske Tidende (2006). „Medieudspil med sød musik og falske toner“ (leder), Berlingske Tidende, 10. maj 2006, 2. sektion, Magasin, p. 8.

Brandt, Henrik H. (1998). „Ny DR-chef lover alsidighed“, Jyllandsposten, 18. maj, 1998, Sport, p. 5.

Bredsdorff, Thomas (1995). „Det almennyttige tv“, Politiken, 13. januar 1995, kultur og debat, p. 8.

Carstensen, Ivar (1998). „Det går DR-udad“, Berlingske Tidende, 11. januar 1998, 2. sektion, p. 6.

Connolly, William (1993). The Terms of Political Discourse, Third Ed., Princeton, N.J: Princeton University Press.

Damgaard, Bo (2006). „TV 2s DNA - og det kommende medie- og filmforlig“. http://producent.tv2.dk/article.php?id=3912279

DR (1995). Radio og TV i folkets tjeneste. Det fremtidige medielandskab, Kbh: DR.

DR (1998). Programkvalitet (Rapport om kvalitetsprojektet i DR), København: DR.

DR (1999). Danskernes DR - DRs ønsker og forslag til en mediepolitisk af- 
tale, København: DR.

DR (2005). DR for dig og hele Danmark. Ønsker og løfter til mediepolitisk aftale 2007-10, København: DR.

Erichsen, Bjørn (1999). „Mere og bedre dansk tv skal erstatte satellitskrald“ (interview), pp. 23-25 i Danskernes DR - DRs ønsker og forslag til en ny mediepolitisk aftale, København: DR.

Hansen, Carsten (2000). „Public service, demokrati og politikere“, Den Frie Larerskole, vol. 46, no. 4, pp. 26-27.

Hedetoft, Ulf (1999). „The nation-state meets the world. National identities in the context of transnationality and cultural globalisation“, European Journal of Social Theory vol. 2, no. 1, pp. 71-94.

Jelved, Marianne (1992). „Fokus på pressen“, Berlingske Tidende, 15. november 1992, 1. sektion, p. 15.

Jensen, Lasse (1996). „Balladen om farveladen“, Politiken, 15. juni 1996, Kultur og debat, p. 3.

Kaarsholm, Lotte Folke (2006). „Kulturmagten: Må Gud lugte af cerut?“, Information, 4. maj 2006, pp. 14-15.

Knudsen, Anne, Christian S. Nissen \& Lasse Jensen (2005). „For at nå hjernen skal man gennem maven“, Lettre Internationale, nr. 7, pp. 18-21.

Knudsen, Lisbeth (1999). „Nyheder 24 timer i døgnet“ i Danskernes DR DRs ønsker og forslag til ny mediepolitisk aftale, København: DR.

Knudsen, Lisbeth (2002). „Kampen om de originale nyheder“, pp. 88-89 i Frank Esmann (red.), Nyhedskriterier i det 21. århundrede, København: DR.

Kulturministeriet (2002). Public Service-kontrakt mellem DR og kulturministeren for perioden 1. januar 2003 til 31. december 2006, København: Kulturministeriet.

Kulturministeriet (2003). Tilladelse til TV2/Danmark A/S til at udøve public serviceprogramvirksomhed, København: Kulturministeriet.

Kulturministeriet (2006). Mediepolitisk aftale for 2007-10. København: Kulturministeriet.

Libak, Anna (1996). „For folkets skyld“, Weekendavisen, 20. september, 1996, 2. sektion, p. 7.

Medieudvalget (1995). Betcenkning om de elektroniske medier, København: Statsministeriet. Publiceret på http://smu.imv.au.dk/elmed/elmed_idx.html

Mortensen, Frands (1994). „Public service i informationssamfundet,“pp. 305-29 i Info-samfundet år 200o - Rapport fra udvalget om 'Informa- 
tionssamfundet år 200o'. København: Forskningsministeriet.

Mouritsen, Per (2006). „The particular universalism of a Nordic civic nation: Common values, state religion and Islam in Danish political culture“, pp. 70-93 in T. Modood, A. Triandafyllidou \& R. Zapata-Barrero (eds), Multiculturalism, Muslims and Citizenship. A European Approach, London: Routledge.

Nissen, Christian S. (1994). „I (tv)folkets tjeneste“, Politiken, 25. august 1994, kultur og debat, p. 3.

Nissen, Christian S. (1999). „DR for alle danskere“ (interview), pp. 20-22 i Danskernes DR - DRs ønsker og forslag til en ny mediepolitisk aftale, København: DR.

Nissen, Christian S. (2005). „The Public Service Nun. A Subjective Tale of Fiction and Facts“, pp. 317-25 in Cultural Dilemmas in Public Service Broadcasting, Göteborg: Nordicom.

Nissen, Christian S. (2006). „Det er næsten for meget af det gode!“, Information, 19. maj 2006, pp. 14-15.

Rørbech, Michala (1998). „Fjernsyn skal provokere“, Aktuelt, 28. november 1998, p. 16.

Sepstrup, Preben (1994). Tv i kulturhistorisk perspektiv, 1954-1994, Århus: Klim.

Skinner, Quentin (1989). „Language and Political Change“, pp. 6-23 in James F. Farr, Terrence Ball \& Russel Hanson (eds), Political Innovation and Conceptual Change, Cambridge: Cambridge University Press.

Slumstrup, Finn (1992). „Radio for de få og for de mange“, Berlingske Tidende, 30. juni 1992, 2. sektion, p. 4.

Syvertsen, Trine (1992). „The Many Uses of the 'Public Service’ Concept“, Nordicom Review, vol. 13, nr. 1, pp. 5-12.

Søndergaard, Henrik (1995). Public Service i dansk fjernsyn: Begreber, status og scenarier, København: Medieudvalget, Statsministeriet. Rapport publiceret på

http://smu.imv.au.dk/soendergaard/soendergaard_idx.html

Søndergaard, Henrik (2003). „Globalisation and National Identity in Danish Television: The Return of the Nation“, pp. 91-127 i Stig Hjarvard (ed.), Media in a Globalised Society, Copenhagen: Museum Tusculanum Press.

Thygesen, Peter (1993). „Minister langer ud efter DR og TV 2, Politiken, 8. december, 1993, 2. sektion, p.1.

TV 2 (1995). TV 2 - Dansk TVi konkurrence, København: TV 2/Danmark. 